2016

\title{
A Law of Just Transitions?: Putting Labor Law to Work on Climate Change
}

David J. Doorey

Follow this and additional works at: http:// digitalcommons.osgoode.yorku.ca/olsrps

Part of the Environmental Law Commons, and the Labor and Employment Law Commons

\section{Recommended Citation}

Doorey, David J., "A Law of Just Transitions?: Putting Labor Law to Work on Climate Change" (2016). Osgoode Legal Studies Research Paper Series. 164.

http://digitalcommons.osgoode.yorku.ca/olsrps/164 


\title{
OSGOODE HALL LAW SCHOOL \\ LEGAL STUDIES RESEARCH PAPER SERIES
}

Research Paper No. 35

Volume 12, Issue 7, 2016

\section{A Law of Just Transitions?: Putting Labor Law to Work on Climate Change}

\author{
David Doorey
}

This paper can be downloaded free of charge from: http://ssrn.com/abstract=2680241

Further information and a collection of publications from the Osgoode Hall Law School Legal Studies Research Paper Series can be found at:

http://www.ssrn.com/link/Osgoode-Hall-LEG.html

\section{Editors:}

Editor-in-Chief: Carys J. Craig (Associate Dean of Research \& Institutional Relations and Associate Professor, Osgoode Hall Law School, York University, Toronto)

Production Editor: Kiana Blake (Osgoode Hall Law School, York University, Toronto) 
Osgoode Legal Studies Research Paper No. 35

Vol. 12/ Issue. 7/ (2016)

\title{
A Law of Just Transitions?: Putting Labor Law to Work on Climate Change
}

\author{
David Doorey
}

\begin{abstract}
:
Climate change will dramatically affect labor markets, but labor law scholars have mostly ignored it. Environmental law scholars are concerned with climate change, but they lack expertise in the complexities of regulating the labor relationship. Neither legal field is equipped to deal adequately with the challenge of governing the effects of climate change on labor markets, employers, and workers. This essay argues that a legal field organized around the concept of a 'just transition' to a lower carbon economy could bring together environmental law, labor law, and environment justice scholars in interesting and valuable ways. "Just transitions" is a concept originally developed by the North American labor movement, but has since been endorsed by important global institutions including the International Labour Organization and the U.N. Environmental Program. However, the prescriptions that would guide a policy of just transition have been under-explored in the legal literature. This paper marks an important early contribution to this challenge. It explores the factual and normative boundaries of a legal field called Just Transitions Law and questions whether such a field would offer any new, valuable insights into the challenge of regulating a response to climate change.
\end{abstract}

\section{Keywords:}

Climate change, environmental justice, environmental law, just transition, labor law, legal taxonomy, unions, non-governmental organizations, transnational law

\author{
Author(s): \\ David Doorey \\ York University \\ E: ddoorey@yorku.ca
}




\section{A LAW OF JUST TRANSITIONS?: PUTTING LABOR LAW TO WORK ON CLIMATE CHANGE*}

There appears to be an emerging framework that allows for a Just Transition to operate on several levels, ranging from the global-societal level down to workplaces and local communities. This framework is grounded in some well-established social practices in the face of job challenges, and is reflected in the ongoing work of the ILO, the trade unions, national and local governments, business and industry, and community-based organizations. However, it is a framework that has been structured around a principle and a goal. The principle holds that the costs and benefits of a transition to sustainability should be shared widely across society. The goal is to generalize this principle at the level of policy. Steps are being taken here and there to turn the Just Transition approach into reality, but there is still a long way to go before it becomes a policy norm.

- United Nations Environmental Programme, 2008'

\section{INTRODUCTION}

The 'Law of the Horse' is a well-worn metaphor used by legal scholars to demonstrate the quintessential non-legal field. ${ }^{2}$ The anecdote proceeds like this. Lots of law concerns horses: consumer law, animal welfare and veterinary laws, gaming law, tort law, and so forth. We could cluster these disparate laws together, stamp the name Horse Law on it, and call it a new field of legal study and practice. Lawyers who practiced in the field could be 'Horse Lawyers', law schools could offer courses in Horse Law, and bar associations could charter new Horse Law chapters. The value of the anecdote rests in the claim that we do not recognize the Law of the Horse as a distinct legal field, and we are therefore challenged to ask why not. What distinguishes the non-legal field

* My thanks for helpful comments to Carla Lipsig-Mumme, Harry Arthurs, Dimitris Stevis, JB Ruhl, James Salzman, Alice Kaswan, and participants at the 'Work in a Warming World' conference at the University of Toronto in 2013 and the Labour Law Research Network Conference at the University of Amsterdam in 2015, where earlier versions of this paper were presented. Thank you to Natalie Macdonnell for valuable research assistance

${ }^{1}$ United Nations Environmental Program, GreEN JOBS: TOWARDS DECENT WORK IN A Sustainable, LOW-CARBON WORLD (2008), http://www.unep.org/PDF/UNEPGreenjobs_report08.pdf, 278.

${ }^{2}$ K. Llewellyn, Across Sales on Horseback 52 HARV. L. REv. 725 (1939) at 735; F. Easterbrook, Cyberspace and the Law of the Horse U. CHIC. LEgAL F. 207 (1996); T. Aagaard, Environmental Law as a Legal Field: An Inquiry in Legal Taxonomy 95 CORNeLL L.J. 221 (2010); J. Ruhl \& J. Salzman, Climate Change Meets the Law of the Horse, 62 Duke J.L. 975 (2013); H. Koh, Is There a "New" New Haven School of International Law?, 32 Yale J. INT'L. L. 559 (2007); D. Ibrahim \& D. Smith, Entrepreneurs on Horseback" Reflections on the Organization of Law, 5 Arizona L. Rev. 7 (2008); Lawrence Lessig, The Law of the Horse: What Cyberlaw Might Teach, 113 HARV. L. REV. 501, 501 (1999) 
Horse Law from the many recognized legal fields, such as consumer, family, insurance, labor, and environmental law $9^{3}$

All new legal fields must confront their Law of the Horse moment, when a decision is made that a new legal field is warranted or desirable because developments in the law or in the world around us have outgrown existing legal taxonomies. Environmental and labor law confronted theirs at different points in the mid to late $20^{\text {th }}$ century. Labor law came into its own as a distinct legal field in the years surrounding the Second World War; environmental law is a much newer field, dating only from the 1970s. Before that, there were common law torts, rules of contract, and government regulations affecting labor and the environment, but no one had cobbled them together and suggested they be treated as distinct legal fields. Something happened that spurred their recognition as new, distinct fields of legal study. Other legal fields have had their Law of the Horse moment more recently. Health law is an example, as is energy law ${ }^{5}$, sports law $w^{6}$, technology or cyber law ${ }^{7}$, entrepreneurial law ${ }^{8}$, and disaster law'.

Sometimes new legal fields evolve as corollaries of established fields, or at least an attempt is made to accomplish this result. This evolutionary process has been taking place in both environmental

\footnotetext{
${ }^{3}$ The rise of Equine Law in academic and practitioner writing perhaps threatens the saliency of the Horse Law anecdote: S. McEnvoy, The Rise of Equine Activity Liability Acts 3 AnIMAL L. 201 (1997); J. Fershtan, Michigan Equine Activity Liability Act: Are We Galloping in Circles, 92 MicH. BAR J. 22 (2013). A better example of a non-legal field may be Brian Langille's "Swimming Pool Law”: Brian Langille, Labour Law's Back Pages in Guy Davidov \& Brian Langille (eds), Boundaries and Frontiers of LABOuR LAW (2006) [hereinafter Boundaries], 2 at 15 . But the challenge posed by the anecdote remains the same: When is it appropriate to reorganize or rebundle laws into a new legal field, and how do we know when "we have hit upon a useful category?", Id at 16.

${ }^{4}$ W. Mariner, Toward an Architecture of Health Law 35 AM. J.L. \& MED. 67 (2009); E. Elhauge, Can Health Law Become a Coherent Field of Law?, 41 WAKE FOREST L. REV. 365 (2006)

${ }^{5}$ Ruhl \& Salzman, supra note 1 at 999-1000.

${ }^{6}$ Paul Weiler, et al, SPOrts And the Law: TeXt, CaSes, AND Problems (4 ${ }^{\text {th }}$ Ed, 2010)

${ }^{7}$ Lessig, supra note 2; F. Easterbrook, Cyberspace and the Law of the Horse" U. CHIC. LEGal F. 207 (1996)

${ }^{8}$ Ibriham \& Smith, supra note 1.

${ }^{9}$ D. Farber, J. Chen, R. Verchick, \& L. Sun, Disaster LAW AND POLICY (2 $2^{\text {nd }}$. Ed. 2010)
} 
and labor law in recent years. Labor law scholars fear the erosion and perhaps eventual demise of their field as the standard employment model and 'labor' as a class and a movement erodes. ${ }^{10}$ They have sought to reinvent the field as labor market law"11, or the law of economic subordination and resistance $^{12}$, among other possibilities. In environmental law, climate change is perceived by many to be a game changer that will welcome unprecedented new challenges that will strain the traditional boundaries and coherence of the field as presently constructed. ${ }^{13}$ Environmental law scholars have proposed new legal fields such as climate change law" ${ }^{\prime 14}$, climate adaptation law" ${ }^{15}$, and environmental justice law ${ }^{16}$. The futures of both environmental and labor law are uncertain.

This existential crisis the two disciplines share. Beyond that, they traditionally have had little in common. They are concerned with difficult sorts of social and economic problems; they are balancing different types of interests; they deploy different legal rules, techniques, and modes of reasoning, and use different discourses. Environmental law scholars and lawyers rarely speak to their labor law counterparts. They publish in different journals, attend different conferences, appear before different tribunals. The goals and outcomes of environment and labor law often conflict. Labor law is concerned with producing more and better jobs, a process often enabled by strong

\footnotetext{
${ }^{10}$ See, e.g., collected works in Davidov \& Langille, Boundaries, supra note 2

${ }^{11}$ Paul Davies \& Mark Freedland, TOWARDS A FleXIBLE LABOR MARKET (2007); Harry Arthurs, Charting the Boundaries of Labor Law: Innis Christie and the Search for an Integrated Law of Labor Market Regulation 34 DAL. L.J. 1. (2011)

${ }^{12}$ Harry Arthurs, Labour Law as the Law of Economic Subordination and Resistance: A Counterfactual? (2012), OsgOODE CLPE REsearch PAPER No. 10/2012: http://papers.ssrn.com/sol3/papers.cfm?abstract_id=2056624

${ }^{13}$ Aagaard, supra note 3 at 223; D. Tarlock, Is There a There in Environmental Law. 19 J. LAND USE \& ENVTL. L. 21 (2004) at 215-217

${ }^{14}$ J. Dernback \& Seema Kakade, Climate Change Law: An Introduction, 29 EnERGY L. J. 1 (2008); J.B. Ruhl, What is Climate Change Law? OUPblog (22 August 2015) http://blog.oup.com/2015/08/what-is-climate-change-law/

${ }^{15}$ Ruhl \& Salzman, supra note 1; R. Craig, Stationarity is Dead-Long Live Transformation: Five Principles for Climate Change Adaptation Law, 34 HARV. ENVTL. L. REV. 9

${ }^{16}$ A. Schwartz, The Law of Environmental Justice: A Research Pathfinder 25 ENVTL. L. REP. $10,543(1995)$,
} 
consumerism ethic. ${ }^{17}$ Environmental law too is concerned with job creation and preservation, but also with the impacts of consumerism and production on climate, air, and water quality and other harmful effects on the natural environment. The seeds for conflict in this are readily apparent, and environmentalists and labor organizations have frequently found themselves on different sides of policy debates. ${ }^{18}$

For these reasons, and more, the prospects for the emergence of a legal field that brings together labor and environmental law seem bleak. On the other hand, both fields are in a period of selfreflection, facing the prospect of an uncertain future. This uncertainty has led scholars in the respective fields to look outward in search of potential allies, and to contemplate new narratives around which their fields could be adapted to ensure their continued vitality and relevance. It is hardly surprising that environmental law scholars would focus on climate change as a possible foundation around which to organize a revitalized legal field. Climate change poses among the greatest, most complex legal policy challenges humanity faces today, and traditional environmental law is obviously well situated to be part of the solution. ${ }^{19}$

But climate change is a complex, cross-sectional problem that will have implications for many other fields of law as well, including labor law. Some jobs and industries will disappear, while others will emerge or expand. An economic transition towards 'green jobs' may introduce new challenges to existing legal models; new pressures will be brought to bare on unemployment, adjustment, and training strategies; labor market patterns and practices may be affected in unpredictable ways as

\footnotetext{
${ }^{17}$ See the Royal Society, Towards Sustainable Consumption (2000), arguing that present trends in consumption are unsustainable and must be restrained, particularly in rich countries.

${ }^{18}$ Ben Obach, New Labor: Slowing the Treadmill of Production, 17 OrGanizaTION \& ENV'T 337 (2004)

${ }^{19}$ Ruhl \& Salzman, supra note 2 at 978; H. Doremus, Adapting to Climate Change with Law That Bends Without Breaking, 2 SAN Diego J. Clim. \& ENERGy L. 45 (2010)
} 
governments, employers, workers, and unions adapt and adjust to environment-related changes. ${ }^{20}$ There will be winners and losers in labor markets, and labor law has always been interested in these sorts of distributional, justice-based concerns.

However, labor law scholars have thus far participated little in the ongoing debates about climate change, and its potential impact on law, legal scholarship, and legal taxonomy. This article marks an early contribution to that discussion. It theorizes a new legal field called Just Transitions Law (JTL). The concept of "just transitions" has roots in the global labor movement, but more recently important international legal bodies, including the International Labour Organization (ILO) and the United Nations Environmental Program (UNEP), have recognized its potential contribution to public policy at both the national and supranational levels. ${ }^{21}$ JTL advocates transitional legal and policy responses and planning that recognize the need for economies to move towards cleaner jobs and production techniques in order to reduce greenhouse gases (GHGs). At the same time, it argues that those policies must be guided by a theory of justice that recognizes that economic transformations of this sort will produce both positive and negative impacts for workers, communities, and nations, and that these impacts should be distributed in a just and equitable manner. Therefore, the boundaries of JTL would be defined by both a factual matrix [laws that affect and influence the transition towards a lower GHG economyl, and a normative theory of justice [the distribution of costs, risks, and rewards associated with this transition should be distributed in a just manner].

\footnotetext{
${ }^{20} \mathrm{~S}$. Dupressoir et al., Climate CHANGE AND EMPLOYMENT: IMPACT ON EMPLOYMENT IN THE EUROPEAN UNION: 25 OF CLIMATE CHANGE AND CO2 EMISSION REDUCTION MEASURES BY 2030 (Brussels: ETUC; Social Development Agency; Wuppertal Institute, 2007); Carla LipsigMumme (ed), Climate at WORK (2013)

${ }^{21}$ UN Conference on Sustainable Development, RIO+20, The Future We Want (2012) http://www.uncsd2012.org/content/documents/727The\%20Future\%20We\%20Want\%2019\%20Jun e\%201230pm.pdf, para. 152; ILO, Climate Change AND LABOUR: The NeED FOR A JuST TRANSITION (21 March 2011), http://www.ilo.org/actrav/what/pubs/WCMS_153352/lang-en/index.htm
} 
We are no doubt a long way from recognizing JTL as a distinct legal field. However this paper argues that there is nevertheless value in theorizing about what such a legal field might look like. The exercise encourages scholars of labor law, environmental law, and environment justice (among other legal fields discussed in this paper) to examine their fields through a different critical lens. When we examine at the challenge of governing climate change through JTL, we might see new paths of dialogue and regulatory strategies that would be missed if the various legal fields remain enclosed within their own intellectual silos. The paper proceeds as follows. Part 2 considers the legal taxonomy scholarship in order to assess when it is appropriate to develop new legal fields, as well as the significance of this exercise to our understanding of the law. Part 3 examines recent efforts by legal scholars to develop a legal field organized around the defining feature of climate change, noting the absence of absence of labor law voices in this debate. Part 4 explores the origins of labor and environmental law as distinct legal fields and the challenges presently confronted by both fields. The challenges of bringing labor and environmental law together are explored in Part 5. Finally, in Part 6, the paper discusses three possible proposals for bringing labor law insights into the climate change dialogue, including the most promising option of developing a Law of Just Transitions. The paper concludes by sketching the broad contours of the subject matter that would comprise JTL.

\section{LEGAL TAXONOMY}

Legal taxonomy, the categorization of legal fields, helps construct our understanding of legal knowledge and the role of law in society. ${ }^{22}$ Recognizing a legal field of study can legitimize not only the lawyers and academics who practice and research in the field, but also the non-governmental

${ }_{22}$ S. Smith, Taking Law Seriously, 50 U. ToronTo LJ. 241 (2000) at 244: "We draw classifications in law not just for the sake of classifying but because classifying rules, cases, and so on is a large part of what acquiring legal knowledge means"; S. Warren \& Loius Brandeis, The Law of Ponds 3 HaRv. L. REV. 1 (1889) 
organizations (NGOs) and 'think tanks' that inhabit it. This recognition can influence not only resource allocation and access to funding for those actors, but also the weight given their opinions and arguments. ${ }^{23}$ Legal fields produce legal experts whose specialization give credibility to the field in public policy debates. Specialized lawyers go forth into their field and develop new legal rules, new techniques, and new modes of legal reasoning that can impact social and economic policy.

Professor Emily Sherman described the benefits of legal categorization as follows:

[O]rganisation of law into categories...facilitate[s] legal analysis and communication of legal ideas... [A] comprehensive formal classification of law provides a vocabulary and grammar that can make law more accessible and understandable to those who must use and apply it. It assembles legal materials in a way that allows observers to view the law as a whole law. This in turn makes it easier for lawyers to argue effectively about the normative aspects of law, for judges to explain their decisions, and for actors to coordinate their activities in response to law. ${ }^{24}$

The growth of environmental law as a recognized field of study in the early 1970s gave greater prominence and influence to professional environmental law associations. ${ }^{25}$ Strong legal fields have a symbiotic and sometimes embryonic relationship with government departments and government funding. For example, as labor law hit its peak of influence in the 1960s-1970s, so too did the influence of labor ministries and labor departments within government, and as collective bargaining faded, so too did labor law's influence in government and in the legal academy. ${ }^{26}$

${ }^{23}$ Ruhl \& Salzman, supra note 1 at 989: "Depending on the circumstances, then, creation of a new field can serve political ends by legitimating a social movement, enhance efficiency by providing a focal area for technical expertise, ensure effectiveness by reorienting laws and policies in a more productive structure, or some combination of all three."

${ }_{24}$ E. Sherwin, Legal Positivism and the Taxonomy of Private Law in STRUCTure AND Justification in Private Law: Essays for Peter Birks (C. Rickett \& R. Grantham, eds, 2008) 103 at 119; Aagard, supra note at 226-27.

${ }^{25}$ For example, the Canadian Environmental Law Association was formed in 1970, just as law schools began to teach Environmental Law as a distinct course. In 1978, the Ontario government began funding the organization as a specialty legal clinic. See CELA website: http://www.cela.ca/whoweare, and discussion of CELA's origins in Emond, supra note .

${ }^{26}$ See discussion in Harry Arthurs, What Immortal Hand or Eye? Who Will Redefine the Boundaries of Labor Law?' in Davidov \& Langille, Boundaries, supra note 3, 373 at 375; Cynthia Estlund, The Death of Labor Law? 2 Annual Review of Law \& Social Sciences 105 (2006) 
Some legal fields owe their distinction to a legal mode of reasoning or rationality. Tort and contracts are examples. ${ }^{27}$ Legal fields such as environmental, labor, sports, and family law acquire their legitimacy, on the other hand, by offering insights into specialized corners of our world. As Professor Brian Langille has explained, "[s]ubjects like labor law take a dimension (a chunk, a slice) of human life such as work, family, or trade between nations, and then draw together all of the law which applies to that aspect of life. ${ }^{28}$ What interests legal taxonomists is the question of which slices of life make sense as hubs around which to bundle legal rules into distinct legal fields. Langille describes the controversy as follows:

$[\mathrm{H}]$ ow is one to know whether one has carved up reality 'at the joint' as it were. How do we know we have a coherent and appropriate subject if we obtain it by simply looking at life without a guiding legal framework to tell us where to carve? On this approach one could (and some have) come up with categories such as 'swimming pool law'... The thinking ishere is a part of reality, swimming pools, and we should draw together all of the law which applied to them (people can be injured in them, they can be bought and sold, they raise planning and environmental issues) and write a text, of offer a course, to satisfy our need to address all of these issues comprehensively. ${ }^{29}$

We do not could cobble together all those laws that affect horses, or swimming pools, because legal scholars do not do believe those slices of life are meaningful in a legal sense. ${ }^{30}$

The task of legal taxonomy is to identify which 'slices of life' are factually distinct and legally meaningful. ${ }^{31}$ Scholars have described this exercise in different terms. However, common to most accounts is the idea that legal fields should contribute something new to our understanding of the world and law's role in it, which might otherwise be missed if law was not categorized in this way. ${ }^{32}$ There must be coherence to the legal story that is produced by the legal field, such that it improves

${ }^{27}$ Langille, supra note 3 at 15

${ }^{28}$ Id. at $15-16$.

${ }^{29} \mathrm{Id}$.

${ }^{30}$ Ibriham \& Smith, supra note 2 at 77.

${ }^{31}$ Id at 79.

${ }^{32}$ Langille, supra note 3 at 16. 
our understanding of law if we organize legal materials together in this way. ${ }^{33}$ This is Langille's point when he notes that a proper carving up of reality into a legal field should result in the whole being greater than the sum of its parts: "[T]here must be a benefit to be obtained from an overview of all of the law which bears upon our chosen category in the form of insight which would be lost if we did not carve reality here". ${ }^{34}$ Aagaard makes essentially the same point when he argues that a legal taxonomy "is useful if the organizational framework reflects patterns that reveal something important to us about the materials being classified. ${ }^{{ }_{35}}$

Those patterns include factual similarities that make it is sensible, and feasible, to bundle law together at a particular point, such as "laws affecting employment" or "laws relating to the pollution”. However, factually distinct patterns alone are a weak form of legal coherence. Factual patterns can change or become more complicated in ways that overburden a legal field founded on little more than a distinct factual narrative. A stronger coherence is driven by a clear, shared value or set of values that guides how we think about law in a particular subject domain. ${ }^{36}$ Legal fields that derive their coherence not just from factual commonality, but also from a shared underlying value or belief system, from "a set of distinctive, fundamental principles" ${ }^{{ }^{37}}$ or "a constituting narrative" are more versatile and adaptive. They are also more likely to expose helpful patterns in the law that advance our understanding of our world, or that expose existing limitations in the law.

\footnotetext{
${ }^{33}$ Aagaard, supra note 1 at 226; D. Solove, A Taxonomy of Privacy, 154 U. PA. L. REv. 477 (2006) at 484; Langille, supra note 2 at 19.

${ }^{34}$ Langille, id. at 16.

${ }^{35}$ Aagaard, supra note 2 at 227; E. Elhauge, Can Health Law become a Coherent Field of Law 41 WAKE FOREST L. REV. 391 (2006) at 370: "[D[o we gain insights from thinking as a group about the set of legal materials grouped under this rubric?”; Lessig, supra note 3 at 502; Ibriham \& Smith, supra note 3 at 84 [a field of study should offer "unique insights about law"]

${ }^{36}$ Aagaard, supra note 2 at 231.

${ }^{37}$ Tarlock, supra note 13 at 218, 228: "One of the primary characteristics of a distinct area of law is that it contains a relatively unique set of core principles distinguishing it from other areas of law".

${ }^{38}$ Langille, supra note 3 at 19.
} 
New legal fields emerge when legal scholars in the field decide to carve up the world in an original manner. This can occur because existing legal categories are missing an important part of the story about the law that can be told only if the law is reorganized as proposed. That is the story of labor law, for example, as will be recounted below. Sometimes new legal fields are proposed in the wake of fundamental changes in the factual matrix that underpin established legal fields, or in recognition of significant new events that strain the boundaries of existing legal classifications. Internet or cyber law is an obvious example..$^{39}$ Climate change may be another; its widespread impacts could have profound effects on our social and economic models.

\section{Climate Change LaW?}

Environmental law scholars are debating whether existing legal classifications are sufficient to explain, conceptualize, and manager the challenges introduced by climate change. Professors Ruhl and Salzman have argued that, "climate change will impose radical changes on society and that the law will...need to adapt in similarly radical ways"..$^{40}$ New legal fields have been proposed to take up that task, including "climate change law" ${ }^{* 1}$ and "climate adaptation law" climate change calls into question base line assumptions that have shaped existing social, economic, and legal patterns. As a result, legal fields that relate to biophysical change-environmental law, water law, natural resources law, and land use law especially, but also agricultural law, insurance law, and littoral-property rights-are ill-equipped to deal with the dramatic changes that will be wrought

\footnotetext{
${ }^{39}$ Lessig, supra note 2; Easterbrook, supra note 7.

${ }^{40}$ Ruhl \& Salzman, supra note 2 at 981. See also: M. Zinn, Adapting to Climate Change: Environmental Law in a Warmer World (2007), 34 ECOLOGY L.Q. 61; Craig, supra note 15 at 17; R. Pierce, Jr., Legal Disputes Related to Climate Change Will Continue for a Century, 42 ENVTL. L. 1257 (2012).

${ }^{4}$ Dernbach \& Kakade, supra note 14; J. Peel, Climate Change Law: The Emergence of a New Legal Discipline 32 Melbourne U. L. Rev. 922 (2008)

${ }^{42}$ Ruhl \& Salzman, supra note 2; Craig, supra note 15; M. Gerrard \& K. Kuh (eds.), The Law of Adaptation to Climate Change: United States and International Aspects ( 2012 )
} 
by climate change. ${ }^{43}$ These scholars argue that when we "look out the window" to see what is going on in the real world ${ }^{4}$, we should focus on climate change, and all of the ways that it engages the law, or should engage the law. Only a legal field that organizes law around the unifying concept of climate change will be responsive enough to deal with the complexity of a warming world.

Proposed legal fields like climate change law or climate adaptation law would reclassify law along ecological fault lines. They would cross traditional legal fields and (re)bundle together all laws that relate in some way to either the causes or effects of climate change. Whether this exercise would result in a meaningful, distinctive, coherent legal field-whether it would add something new to our legal understanding that might otherwise be missed-is a matter of scholarly debate. A taxonomy based around climate change would also raise difficult boundary issues: given the vast range of human activities that can impact climate, and all of the laws that regulate those activities, how do we know a climate change law when we see one?

How that question is answered could have important implications for other legal fields, including labor law. When we 'look out the window' at the existing legal world through the lens of climate change, what parts of the law that presently govern or effect work relations do we see? So far, the legal scholars leading the charge for a new legal field organized around climate change have seen little that interests them. Legal scholars have explored possible intersections of climate change and other legal fields, such as: energy law, water law, maritime law, immigration law, environmental law, land planning law, insurance law, disaster law, even military law and securities (disclosure) law. ${ }^{45}$ But labor law is mostly ignored. There are few (if any) articles, books, or chapters on 'climate change and labor law'. This does not mean that climate change will have no impact on employment and

\footnotetext{
${ }^{43}$ Ruhl \& Salzman, id. at 1012.

"The window metaphor is borrowed from Langille, supra note 3 at 15 .

${ }^{45}$ See the collection of articles in Gerrard \& Kuh, supra note 42, covering off many of these subject areas. See also: A. de Sherbinin et al., Preparing for Resettlement Associated With Climate Change 334 SCIENCE 456 (2011)
} 
work patterns; there is wide spread belief that it will. There is a large body of non-law scholarship examining tensions and cooperation between environmental groups and labor organizations. ${ }^{46}$ But the intersection of climate change law and labor law remains largely unexamined.

This might be explained by a lack of expertise in labor law by those leading the climate change law discussion. Or, there may be an assumption that existing labor laws are robust enough to adapt to climate change without any fundamental transformation: climate change will no doubt alter work patterns, but the details of how working conditions are governed by law need not undergo a dramatic transformation due to a warming climate. Just like family law, for instance, it is possible to imagine new factual scenarios and challenges arising within the labor law field caused by climate change. But if we accept that the laws we presently use to govern family-related and work-related problems are pliable enough to manage these new scenarios, then we would not expect much emphasis within labor law on climate change and environmental issues. ${ }^{47}$

However, law could also be re-organized in different ways that draw greater attention to important interrelationships between environmental, climate change, and labor law. Remapping the boundaries of law might provide us with a clearer picture of the challenges we face in adapting to climate change. Those challenges include how to protect workers in industries that will suffer or disappear altogether as a result of climate change, while also devising legal and policy mechanisms that will pursue a fair distribution of rewards that will accrue from positive labor market developments due to climate change, including the development of new industries and economic opportunities.

\footnotetext{
${ }^{46}$ See, e.g., B. Obach, New Labor: Slowing the Treadmill of Production?, 17 (3) ORG. \& Env.'T 337 (2004)

${ }^{47}$ Ruhl \& Salzman, supra note 2 at 993-994, discussing how Family Law and other legal fields that do not depend on assumptions about the biophysical world will not be threatened directly by climate change.
} 


\section{A TAXONOMY OF LABOR AND ENVIRONMENTAL LAW}

Although environmental law and labor law are well situated to play important roles in a new legal field organized around climate change and work, the two fields are not natural allies. Labor law is concerned with striking a balance between worker and employer interests, while considering impacts on the economy and society more broadly. While the principal private actors in the labor law system (workers, employers, and their respective associations) sometimes disagree over the share of the economic pie, both sides usually agree that a bigger economic pie is better than a smaller one, that more production is better than less. This expansionary vision must be fed by strong consumer demand and spending.

However, the forces of economic expansion and consumerism are often not aligned with the goals of environmental protection. Alan Schnaiberg describes the drive for ever-expanding production that comes at the expense of environmental degradation as "the treadmill of production". ${ }^{48}$ Labor law facilitates collective bargaining for the purpose of empowering workers to bargain a greater share of the spoils of their economic contribution to production. However, the outcomes of this process, including higher labor costs, propel capital to expand production, while limiting other costs of production. Slowing production, or imposing new costs on employers in order to reduce environmental harm and emissions, sometimes an outcome of environmental law, may be contrary to the goals of labor law, at least in the short term. This potential clash of interests between the goals of labor and environmental law can be better understood if we reflect briefly upon the origins of the two legal fields, and the sources of contemporary angst within both fields.

\section{A. The Origins of Labor Law}

${ }^{48}$ A. Schnaiberg, The Environment: From Surplus to SCARCITY (1980) 
The origins of labor law as a distinct legal discipline vary by nation, fluctuating in large measure on the timing of industrialization, the relative strength and development of indigenous labor movements, and law's efforts to restrain and manage labor conflict. As Professor Harry Arthurs has described, "labour law [in English speaking countries] effectively emerged as a full-blown academic discipline only in the years before and after the second world war." ${ }^{\prime 9}$ That occurred because legal scholars of the day saw value in re-bundling those parts of tort, contract, and administrative law that dealt with work-related disputes and situating them under the new banner of Labor Law. ${ }^{50}$ But what was that value?

This question has received a lot of attention from labor law scholars in recent years. The debate comes in two fundamental parts. The first asks what has been the traditional, or historical, foundation of labor law as a discipline. What made it an appropriate field of legal study during the New Deal era and in the period that followed? The second part asks whether that explanation, or justification, has stood the test of time, and if not, what might replace it as the defining concept or 'constituting narrative', as Langille puts it.

Most labor law scholars agree on the answer to the first part. Labor law evolved to deal with what were perceived by scholars to be the special problems associated with the waged employment relationship, owing to the inherent imbalance of bargaining power that characterized it. ${ }^{51}$ The central normative pillar of labor law was the insight that the contract law model applied to the employment relationship left the individual worker vulnerable to opportunism, coercion, and

\footnotetext{
${ }^{49}$ Arthurs, supra note 12 at 3. See also discussion in Estlund, supra note 26 at 6.2-6.4; Langille, supra note 3.

${ }^{50}$ This section draws heavily on Langille, id. See also David Beatty, Labour Law in a Nutshell, 75 Can. Bar. Rev. (1996)

${ }^{51}$ See e.g. Matthew Finkin, Book Review: The Death and Transfiguration of Labor Law), 33 COMP. LAB. L.\& POL'Y J. 171 (2011-12) at 178-79; Otto Kahn-Freund, LABOR AND THE LAW (1972); Guy Davidov, The (Changing.) Idea of Labor Law, 146 INT. LAB. REV. (2007); Langille, supra note 2 at 23-25; Harry Arthurs, Labour Law After Labour, U. TORONTO L. J. 1 (1995) at 17-18.
} 
injustice at the hands of the more powerful employer. ${ }^{52}$ That injustice was manifest in low pay, long hours, economic insecurity, and dangerous working conditions. Since society has an interest in human beings not being unjustly treated, and in an economic system that produces a fair and sustainable distribution of wealth and privilege, it was deemed necessary and desirable for the state to intervene through law to prevent injustice in the employment relationship. The legal rules used to achieve this ends-both collective bargaining rules and regulatory standards-were the subject of the legal field of labor law. ${ }^{53}$

Central to this understanding of labor law were two concepts captured by the slogans: 'labor is not a commodity' and 'inequality of bargaining power'. Together, they carved out labor law's distinctive normative ground. Inequality of bargaining power is not itself a unique to waged labor, and nor is it considered particularly problematic in the contract law world. However, since decent employment is so central to human social and economic well-being and development, as well as to political stability, labor law's central normative claim is that the employment relationship should not be treated as just another mundane market transaction. ${ }^{54}$ The labor relationship demands a theory of justice, and labor law as an academic legal field was organized around that theory.

The second part of contemporary debates in labor law is less settled. It asks whether this labor law narrative remains persuasive. A number of developments have strained the traditional story. ${ }^{55}$ Firstly, the employment relationship has undergone fundamental changes since the 1940s. Far

${ }^{52} I d$. See also, Hugh Collins, Theories of Rights as Justifications for Labour Law in Davidov \& Langille, Boudaries, supra note 3 at 137.

${ }^{53}$ See Langille, supra note 3 at 23: "Labour law is thus primarily conceived as a set of interventions in the Labor market, that is, in the negotiation process for contracts of employment. That point of all this is, of course, 'justice' in this part of our lives, that is, in employment relationships.... When employees negotiate contracts of employment they suffer from an 'inequality of bargaining power'. As a result, they will not obtain just outcomes."

${ }^{54}$ David Beatty, Labor is Not a Commodity in J. Swan \& B. Reiter, eds., STUdies IN Canadian CONTRACT LAW (1980), 313; Langille, supra note 2 at 105-106.

${ }^{55}$ See Arthurs, supra note 51. 
fewer workers are engaged in the standard, full time employment relationship that most of our existing labor laws are designed to govern. ${ }^{56}$ As a greater segment of the working population falls outside of the traditional employment model, the descriptive, explanatory, and predictive power of legal models designed to instill justice into that model declines.

Secondly, this shift away from standard employment has exasperated the declining presence of trade unions, which were already under threat from a variety of other sources. Economic restructuring in most advanced economic nations away from highly unionized goods manufacturing has cut into union density. ${ }^{57}$ In the United States, unions represent only about 6 percent of private sector workers, and collective bargaining coverage is eroding throughout much of the advanced of the economic world. Collective labor law-the rules governing union organizing, collective bargaining, collective agreements-has always dominated the field of labor law. However, as unions fade in importance, so too has interest in the legal infrastructure designed to regulate their activities. $^{58}$

Thirdly, the importance of 'labor' as a class has declined. ${ }^{59}$ Fewer people define themselves as members of the 'working class', and political parties historically linked to that class are moving away from class-based politics and policy definition. Fourthly, serious, sustained attacks against the core labor law narrative have put the legal field on the defensive for decades. Most notably, neoliberal law and economics scholars have developed powerful market-based critiques of labor law's claim to

\footnotetext{
${ }^{56}$ Katherine Stone, Rethinking Labour Law: Employment Protection for Boundaryless Workers in Davidov \& Langille, Boundaries, supra note 2, 155; Leah Vosko, N. Zukewich, C. Copeland, Precarious Jobs: A New Typology of Employment Perspectives (October 2003), 16; Arthurs, id., at 21.

${ }^{57}$ Leo Troy, Market Forces and Union Decline: A Response to Paul Weiler, 59 U. ChIC. L. Rev. 681 (1992)

${ }^{58}$ Estlund, supra note 26.

${ }^{59}$ Arthurs, supra note 51 at 18-19; M. Crain \& K. Matheney, Labor's Identity Crisis, 89 CAL. L. REV. 1767 (2001)
} 
special legal protections in antitrust laws, and have mocked the claim that inequality of bargaining power in employment creates a social or economic problem requiring protective legislation. ${ }^{60}$

These forces have coalesced to create a crisis in labor law, as noted by Arthurs:

If labor's identity is dissolving, if class generally matters less, if workers' issues have fallen off the public policy agenda, the familiar 'constituting narrative' of labor law ceases to constitute. ${ }^{61}$

This crisis of legitimacy has caused serious soul searching within the labor law academy. Some scholars have sought to redefine 'the boundaries' of the field to ensure its continued relevance moving forward, as we will see below. ${ }^{62}$

\section{B. The Origins of Environmental Law}

Environmental law is an even younger legal field than labor law. It evolved in North America only in the 1970s. ${ }^{63}$ Before then, there was law that regulated issues related to the environment, but the intersection of law and the environment was addressed in tort (nuisance, trespass, riparian rights) and administrative or regulatory laws that touched on pollution and clean water issues. Prior to the 1970s, there were no law school courses called Environmental Law, and no textbooks that consolidated the laws into a coherent field of study. Professor Paul Emond describes the situation as it existed in the late 1960s:

\footnotetext{
${ }^{60}$ Richard Posner, Some Economics of Labor Law, 51 U. Chicago L. Rev. 988 (1984); Richard Epstein, In Defense of the Contract At Will, 51 U. ChicAGo L. Rev. 947 (1984); Richard Epstein. A Common Law for Labor Relations: A Critique of the New Deal Labor Legislation, 92 Yale L.J. 1357 (1992)

${ }^{61}$ Arthurs, supra note at 20

${ }^{62}$ See collection of articles in Davidov \& Langille, Boundaries, supra note 3.

${ }^{63}$ Ruhl \& Salzman, supra note 2 at 982; Aagaard, supra note 2 at 251-82; Richard Lazarus, Thirty Years of Environmental Protection Law in the Supreme Court 17 PACE ENV'T L. REv. 1 (1999); Tarlock, supra note 13; Paul Emond, Are We There Yet? 46 Osgoode H.L.J. 219 (2008) at 222 (explaining how Canadian environment law was initially inspired by developments in the United States, in particular the passage of the National Environmental Policy Act of 1969, 42 U.S.C. 4321)
} 
There was no such thing as "environmental law" in those days. It was not taught in law schools; there were no professional associations charged with promoting the practice of environmental law; and there were certainly no firms" whose practice was exclusively or even partially restricted to environmental law." Instead, there was optimism that, with enough imagination, a good lawyer (or law student) could cobble together tort, property, and perhaps criminal law to stop, or at least severely curtail, any pollution problems. ${ }^{64}$

Professor Lazarus has described how early American environmental lawyers debated the merits of proposing and developing a new legal field of environmental law, and how some believed that the best strategy was to resist the temptation to forge a new field and instead argue that "there is nothing at all unique about environmental law" ${ }^{6.5}$ In the end, this position did not win the day, and a conscious decision was made by leading legal scholars, environmental activists, and policymakers to cobble all of the various tort and administrative laws together under the new heading of 'Environmental Law'. ${ }^{66}$

Environmental law is (mostly) accepted as a distinct legal field today. ${ }^{67}$ However, even among environmental law scholars, there is no clear agreement on what makes it so. The difficulty can be demonstrated in a simple question: How do we know an environmental law when we see one? $?^{68}$ Some statutes seem to be a natural fit, such as environmental protection and clean water legislation. This type of legislation is concerned with 'the natural environment' and the impact of human activity on it. ${ }^{69}$ Yet can environmental law be reduced to the study of laws that have environmental affects? If so, then where does the boundary of environmental law begin and end. As Aargaard

\footnotetext{
${ }^{64}$ Emond, id. at 223. See Ruhl \& Salzman, supra note 2 at 996 for a similar account of the state of environmental law prior to the 1970s in the US.

${ }^{65}$ Lazarus, supra note 63 at 48.

${ }^{66}$ Id.; Ruhl \& Salzman, supra note 2 at 982, 997; Tarlock, supra note 13 at 215.

${ }^{67}$ Lazurus, id., [arguing that the US Supreme Court judges treat environmental law as just a subset of administrative law, rather than a distinct field offering distinct legal insights]; D. Westbrook, Liberal Environmental.Jurisprudence, 27 U.C. DAVIS L. REV. 619 (1993-94) at 619: "Despite being a burgeoning area of practice, environmental law is not a discipline, because it lacks the professional consensus on a coherent internal organization of materials a discipline requires." J. Wexler, The (Non)Uniqueness of Environmental Law, 74 GEO. WASH. L. REV. 260 (2006)

${ }^{68}$ See Westbrook, id. at 632.

${ }^{69}$ See discussion in Aargaard, supra note 2 at 260.
} 
notes: "If environmental law includes all laws that affect the environment, then virtually every law could fall within that definition because almost every law affects human behavior, and almost every human behavior affects the natural environment in some respect.” ${ }^{70}$

This boundary problem has left environmental law scholars struggling to define what distinguishes their field from 'non-fields' like horse and swimming pool law, and concerned about the sustainability of the field. ${ }^{71}$ This is a challenge that frequently arises when legal fields are premised solely or primarily on the basis of factual slice of life, as discussed earlier. If environmental law entails nothing more than the cobbling together of laws that consider the environment, or that impact it in some way, then it "seems uselessly broad". ${ }^{22}$ Put differently, if all we are doing is grabbing at disparate laws that seem to have something to do with the environment and placing them under the banner of environmental law, then it seems unlikely that this field is contributing any genuinely new legal insight-it is not teaching us something we would otherwise miss.

Environmental law scholars have moved on several fronts to meet this challenge. One argument is that modern environmental problems and challenges are too complex and multifaceted to be dealt with piece meal through a spattering of seemingly unrelated tort rules and administrative statutes. ${ }^{73}$ For example, Lazurus has argued that what distinguishes environmental law is the complexity of the causes and effects of 'ecological injuries' with which it is primarily concerned: ecological injuries can be irreversible and continuing; injuries are not jurisdictional specific and can affect broad areas; injuries are often temporally distant, actions now may not result in manifest harm until later; the complexity of ecological harm creates uncertainty, so that much of the law is about risk management rather than actual, provable impact; injuries are usually the result of a chain of events

\footnotetext{
${ }^{70}$ Id. at 262.

${ }^{71}$ Tarlock, supra note 13 at 215-217, discussing the threats to environmental law as a legal field.

${ }^{72}$ Z. Plater, et al., ENVIronmental LaW AND POlicy: Nature, LAW AND SOCIETy (2004) at 5; Aargard, supra note 3 ; Tarlock, id. at 221.

${ }^{73}$ Ruhl \& Salzman, supra note 3 at 998.
} 
and activities, so assigning blame is a highly complicated exercise; the types of damages in environmental law are not always economically quantifiable. ${ }^{74}$ Environmental law tells a "story" about the complexity of cause and effect in the case of ecological damage that is missed when that damage is treated as just another incident of tort or administrative law. ${ }^{75}$

Another approach has been to construct a normative boundary for environmental law, organized around some guiding principles, such as 'protecting the environment' from harm caused by human activities. With this normative agenda in mind, scholars have proposed principles to guide environmental policy and legal decision-making. ${ }^{76}$ David Westbrook argued that environmental law's coherence derives from the fact that it is law's way of responding to the difficult challenge of fitting the normative pursuit of collective environmental protection into the dominant political orthodoxy of 'liberalism' that pervades western thinking and is based in the pursuit of individual autonomy. Because much of what environmental law does cannot be defended as advancing individual human autonomy-indeed, it often restricts that autonomy-it forces us to question our view of the relationship between humanity and the world. Environmental law, says Westbrook, "forces liberal theory to ask after the future".

However, Aagard argues that attempts to link environmental law's coherence to the normative goal of protecting the environment misstate what the field is really about. Much of the law that is considered to fall within the boundary of environmental law is not about 'protecting the environment' at all, or at least that is not it primary objective:

Environmentalism does not predominate in current environmental law. And there is little prospect of that changing significantly in the future. Instead, environmental law reflects a

\footnotetext{
${ }^{74}$ Richard Lazarus, Restoring What's Environmental About Environmental Law in the Supreme Court 47 UCLA L. Rev. 703 (2000)

${ }^{75}$ Id., calling for a better effort by lawyers to "present environmental law's story" to judges.

${ }^{76}$ Tarlock, supra note 13 at 248-253, proposing five principles to guide environmental law policy and decision-making, all premised on a goal of protecting the environment.

${ }^{77}$ Westbrook, supra note 67 vat 709.
} 
balance among a variety of competing values and interests, which include environmentalism but also other, arguably more powerful, values such as maintaining traditional patterns of resource exploitation and resistance to government regulation. ${ }^{78}$

Aagard argues what primarily distinguishes environmental law are its factual characteristics. It deals with 'physical public resources' (public lands, air, water, wildlife) which are not privately owned, and which give rise to complex competing usage claims and well-known collective action problems. ${ }^{79}$ The "special difficulties" associated with regulating conflicting use claims is what "lies at the heart of all problems that arise in environmental law" ${ }^{80}$ Resolving these conflicts is particularly challenging due to the 'pervasive interrelatedness' that defines the world's ecological system. ${ }^{81}$ Actions here can affect ecological outcomes there, though the causal ripple effects may difficult to track, prove, and assess. Environmental law draws attention to this interrelatedness in ways that might be missed if environment-related issues were left to "insular subfields" of law.

\section{THE INTERSECTION OF ENVIRONMENTAL AND LABOR LAW}

Although environmental and labor law scholars have not much interacted over the years, they have recognized that their fields do occasionally overlap, or at least can influence one another. In some respects, legal rules and statutes falling within the scope of labor law are also environmental statutes. The most obvious example is occupational health and safety laws, which control exposure to and use of deleterious substances in work settings. There is overlap when those substances are also

\footnotetext{
${ }^{78}$ Aagard, supra note 2 at 256.

${ }^{79}$ Ibid. at 266; Westwood, supra note 67 at 652; G. Hardin, The Tragedy of the Commons (1968) 162 SCI. 1243 at 1245.

${ }^{80} I d$. at 265 .

${ }^{81} I d$. at 268.

${ }^{82} I d$. at 282.
} 
harmful to the environment, so when unions fight for greater controls on harmful substances in the workplace, they are also making an environmental argument. ${ }^{83}$

However, other than instances of direct statutory overlap of subject matter, the 'environment' has usually been treated as just one of various external systems that can affect labor law. Just as labor laws and the outcomes of workplace level negotiations can be influenced by changes or disturbances in the political, economic, cultural, and social makeup of a society, so too can climate affect labor law outcomes. For example, climate influences the range of labor market activities and employment levels available in a region, as well as the relative bargaining power and strategies of workers, unions, and employers. ${ }^{81}$ Environmental laws can also impact the labor law subsystem. For instance, new regulations limiting emissions or requiring 'green' production equipment or techniques can affect production systems in ways that impact working conditions, cause layoffs, or create downward pressure on labor costs. These effects will influence the negotiating strategy of labor law actors, and possibly shape the substance of rules and practices that emerge from the labor law system.

The point is that environmental law and labor law are semi-autonomous legal fields, inhabited by their own set of actors and operate according to their own logics and discourses. Yet each recognizes the other as an occasional source of exogenous influence. This is how environmental and labor law scholars have traditionally perceived their worlds. Not surprisingly, legal scholars in the two fields have only infrequently interacted. On the other hand, the actors who inhabit the environmental and labor law subsystems have long interacted. For decades, unions and environmental groups have engaged in dialogue, engagement, cooperation, and conflict when their

\footnotetext{
${ }^{83}$ Dimitris Stevis, Unions and the Environment: Pathways to Global Labor Environmentalism, 14 WORKING USA: J. LABOR \& SOC. 145 (2011)

${ }^{84}$ A. Craig \& N. Solomon, The System OF Industrial Relations in Canada $\left(5^{\text {h) }}\right.$ (1996) at 42, and $14-15$.
} 
interests intersect. Cooperation and common cause describes some of those interactions, exemplified by the Blue Green Alliance, a coalition of unions and environmental organizations. ${ }^{85}$ Other times, labor and environmental groups have clashed. ${ }^{86}$ The source of conflict between workers and unions and environmental groups and other citizens usually resides in the age-old trade-off between 'jobs and the environment'. There is a wealth of literature by social movement and labor studies scholars, but rarely legal scholars, examining these interactions. ${ }^{87}$

Labor and environmental regulation can certainly influence the interactions between environmental and labor actors. However, law does not tend to play a major role in the literature that studies those interactions. One reason why is that labor law and environmental law are concerned with fundamentally different policy projects and objectives. Labor law is the system of rules used to regulate work-related conflict between workers and employers. Its objectives are to strike an appropriate balance between employer efficiency interests (productivity and profitability) and worker interests in more decent jobs, within a system characterized by 'inequality of bargaining power'. The objective or environmental law is to strike a different sort of balance, between protection of the environment from harms caused by human activities, on one hand, and the desire to produce or save jobs, on the other hand.

\footnotetext{
${ }^{85}$ See the website of Blue Green Canada: http://www.bluegreencanada.ca/about . The participating organization are: United Steelworkers of America, the Communications, Energy, and Papers Workers Union of Canada, Environmental Defense, Columbia Institute, Penbina Institute, and Tides Canada.

${ }^{86}$ A memorable episode in Canada involved members of Greenpeace chaining themselves to logging equipment in British Columbia, leading to a lawsuit by the unionized loggers, funded by their union, who lost wages as a result of the protest. A court ruled the environmentalist's actions tortious and ordered damages equal to the amount of the loggers lost wages: see Verchere $\mathrm{v}$. Greenpeace Canada (2004), 241 D.L.R. (4th) 327 (B.C.C.A.)

${ }^{87}$ The scholarship on the relationship between unions and environmental groups is immense. Some samples include: F. Rose, Coalitions Across The Class Divide: Lesson form Peace, LABOR, AND ENVIRONMENTAL MOVEMENTS (1999); Ben Obach, LABOR AND Environmental Movements: The Quest For COMmon Ground (2004); Stevis, supra note 83; M. Dreiling, From Margin to Center: Environmental Justice and Social Unionism as Sites for Intermovement Solidarity 6(1) RACE, GENDER, \& CLASS 51 (1998)
} 
Thus, in their own ways, both labor and environmental law are concerned with producing and protecting jobs, while enabling efficiency, productivity, and profitability, within a capitalist economic model. Both involve government imposed legal restrictions on commerce and freedom of contract in pursuit of broader public policy goals. In short, both systems of law impose a countervailing power on unbridled economic activity. But the countervailing interests involved are very different, and often are in in conflict. Labor law aims to protect workers; environmental law seeks to reduce pollution and climate-related harm. The two fields are engaged in different sorts of balancing exercises, requiring different technical expertise, employing different discursive tools and legal logics, with different histories and actors. However, climate change may be bringing the two legal fields together.

\section{Three Proposals For Bringing Labor LaW into the Climate Change DISCUSSION}

Devising policies that tackle climate change while recognizing the need for more decent jobs is among the most difficult policy problems the world faces today. ${ }^{88}$ It is no less a challenge for legal scholars precisely because the complex problem crosscuts multiple fields of law. A non-exhaustive list of legal fields potentially affected by climate change includes labor, environmental, water, securities, energy, human rights, insurance, immigration, tax, civil litigation and class action, torts, contracts, corporate, and international and transnational law. Attempts to cobble together under a single banner all of the law potentially relevant to climate change will run into a familiar problem. What would make that exercise legally meaningful?

${ }^{88}$ Richard Lazarus, Super Wicked Problems and Climate Change: Restraining the Present to Liberate the Future 94 CORNELL L. REv. 1153 (2009) 
As noted above, some environmental scholars have proposed new legal fields such as climate change law or climate adaptation law. Proponents of these new fields argue that no existing field has the capacity to recognize and deal with the complexity of climate change, and its impacts on society and the economy. These proposals vary in their approach to defining the new legal field, but the substance of the law that interests them are mostly environmental laws, along with related fields like energy, water, land use and planning law. ${ }^{89}$ Labor law rarely appears in their sightlines, although sometimes 'justice' issues do. ${ }^{90}$ In particular, as we will discuss later, some environmental justice scholars are very aware of how climate change, and efforts to regulate it, raises important equality and justice issues. ${ }^{91}$

There has to date been little effort to develop a new, coherent legal field that combines insights from labor and environmental law in a manner that could help us wrestle with the complexity of climate change. ${ }^{92}$ This may be due to the fact that labor law scholars have been largely absent from climate discussions. Yet labor lawyers have something important to contribute to the debates about climate change, and law's role in addressing it. A legal model to address climate change should promote public voice, and recognize the many public and private actors already engaged in dialogue, contestation, and problem solving around climate mitigation and adaptation. It should include a theory of justice that recognizes that there will be costs and benefits to societies associated with climate change, which should be distributed in an equitable manner. As noted by Regan, a "climate change framework informed by the lens of labor rights could include both the moral

\footnotetext{
${ }^{89}$ See for example, J. Derbach \& S. Kakade, Climate Change Law: An Introduction, ENERGY L.J. 1 (2008) [charting the legal areas that relate to climate change law, but not including reference to Labor law]...

${ }^{90}$ Ruhl \& Salzman, supra note 2 at 1021 [proposing a legal field of Climate Change Law that includes 'adaptation equity' as one of several guiding normative values].

${ }^{91}$ See e.g., E. Posner \& D. Weisbach, Climate Change Justice (2010)

${ }^{92}$ Katherine Regan, The Case for Enhancing Climate Change Negotiations with a Labor Rights Perspective, 35(1) Columbia J. Environmental L. 249
} 
elements of the individual rights of the laborer and economic focus of traditional climate change agreements." ${ }^{93}$

And climate change demands a regulatory solution that overcomes market failures and well-known collective action problems associated with environmental degradation. ${ }^{94}$ As political commentator and activist Naomi Klein noted in a recent speech about climate change to labor leaders: "It is not hyperbole to say that our future depends on our ability to do what we have so long been told we can no longer do: act collectively. ${ }^{{ }_{0} 5}$ Few legal fields know more about harnessing collective voice and power in pursuit of social and economic justice than labor law. With this in mind, the remainder of the paper explores three possibilities for a new legal field organized around climate change that could bring a measure of internal coherence to a field that will by necessity bring together a wide range of legal fields.

\section{A. A Law of Economic Subordination and Resistance}

Harry Arthurs has offered one vision for a re-imagined role for labor law that has expanded potential for a legal field that could respond to the challenge of climate change. He proposed a 'counter-factual' to the constituting narrative of labor law. He questioned what might have had occurred if, rather than rallying around the slogan "labor is not a commodity", early labor law scholars had carved their reality differently:

Suppose that during the inter-war years-in say 1920 or 1930--...the pioneers of labor law had decided that abuses attributable to disparities of economic power were not unique to labor markets. Suppose that they therefore invented not labor law but 'the law of economic subordination and resistance'? Suppose that they had developed a body of legal learning that dealt comprehensively not just with the regulation of employment relationships and

\footnotetext{
${ }^{93} I d$. At 250.

${ }^{94}$ Hardin, supra note 79 at 1243; T. Yang, Melding Civil Rights and Environmentalism: Finding Environmental Justice's Place in Environmental Regulation 26 HARV. ENV. L. REv. 1 (2002)

${ }_{95}$ Naomi Klein, "Unifor Should Fight For a Green Labor Revolution" Rabble.ca (2 September 2013): http://rabble.ca/news/2013/09/naomi-klein-unifor-should-fight-green-Labor-revolution
} 
labor markers, but of all relationships in which individuals share experiencing economic subordination, resisting it though various strategies of self-defense and seeking legal redress against it in various legal forums. ${ }^{96}$

Arthurs engaged in this counter-factual as a device for proposing a new way forward for labor law. The central insight, the basis upon which this model carves off a portion of reality for legal study, is economic subordination and resistance to it. It builds on the insight that workers in an employment relationship are "but one representative example of the experience of many groups under capitalism, for all of whom there should be some protection. ${ }^{97}$ As Arthurs notes, remapping the legal field in this way offers the potential of new integrations of what have "up to now been separate subjects, specialties or discourses." ${ }^{98}$

We can imagine a legal textbook called The Law of Economic Subordination and Resistance. Arthurs provides us with a list of possible chapters spanning a wide range of subject areas beyond just labor laws and worker and union protests and strikes, including: rent control laws and 'rent strikes'; consumer rights laws and consumer boycotts; welfare laws and welfare 'sit-ins'; competition rules and farmer cooperatives; insider trading and minority shareholder protection laws and investor activism; government banking regulations and public bailouts of corporations and countervailing “Occupy”-like resistance movements; and trade laws and 'anti sweatshop' or anti-free trade campaigns. Arthurs did not include land use and environmental law, and the countervailing environmental justice resistance movement, but he could have.

'Environmental justice' is both a social justice and resistance movement and a strategy of legal engagement. ${ }^{99}$ Environment justice emerged in the United States in the early 1980s in the wake of

${ }^{96}$ Arthurs, supra note 11 at 7.

${ }^{97}$ Id. at 8.

${ }^{98} I d$.

${ }^{99}$ It may also have risen to the level of a distinct legal field, though that is contested. Ruhl \& Salzman, supra note 2, argue that environmental justice is a distinct legal field. My thanks to 
high profile oppositions to the locations of hazardous waste landfills. ${ }^{100}$ Environmental justice activists and scholars surveyed the distribution of benefits and harms flowing from the application of environmental and land use laws and found that the harms were disproportionately burdened by visible minority communities. Like labor law, environmental justice's defining narrative is based in notions of distributive justice and collective voice of economically subordinate groups. ${ }^{101}$ As Kaswan notes, "the environmental justice movement brought together two concepts that had rarely been joined: environment and justice." ${ }^{102}$

Also like labor law, environmental justice has roots in a bottom-up resistance movement critical of a dominant legal system that benefits economically and politically powerful, privileged segments of society. The emphasis in environmental justice is on distributive and political justice, particularly along racial and socio-economic lines, across a variety of legal fields, principally environmental law, land use and planning law, water law, and energy law. Labor law too is concerned with distributive and political justice, its focus being on those laws that intersect at the work site. Because environmental justice treats "environmental problems as only one part of the larger social issues of racism and cultural and economic injustice ${ }^{103 \%}$, it is a natural ally to labor law in a re-imagined legal field organized around Arthurs' theme of subordination and resistance.

Professors Ruhl and Salszman and Professor Alice Kaswan, for a thoughtful email discussion on this issue.

${ }^{100}$ Scholars usually date the birth of environmental justice to the opposition by an African-American community to the placement of a hazardous waste landfill in North Carolina in 1982: Alice Kaswan, Environmental Justice: Bridging the Gap Between Environmental Laws and Justice' (1997), 47 AM. U. L. REV. 221 (1997) [hereinafter "Bridging"] at 226.

${ }^{101}$ The literature on the origins of environmental justice is rich and lengthy. See, e.g., Kaswan, id..; Alice Kaswan, Environmental Justice and Environmental Law 24 FORDHAM ENVIRONMENTAL L. REV. 149 (2013) [hereinafter 'Fordham']; Yang, supra note 92; G. Torres, Environmental Justice: The Legal Meaning of a Social Movement ,15 J.L. \& Com. 597 (1996); Environmental Justice: Bridging the Gap Between Environmental Laws and 'Justice', 47 AM. U. L. REv. 221 (1997); A. Schwartz, The Law of Environmental Justice: A Research Pathfinder, 24 ENVTL. L. REP. 10,543 (1995)

${ }^{102}$ Kaswan, Bridging, supra note 98 at 228.

${ }^{103}$ E. Gauna, Federal Environmental Citizen Provisions: Obstacles and Incentives on the Road to Environmental Justice 22 ECOLOGY L. Q. 9 (1995) at 12. See also, Kaswan, Bridging, id. at 227; L. 
Environmental justice is also central in discussions about the relationship between climate change and the environment, on one hand, and social justice issues on the other. ${ }^{104}$ Some environmental law scholars have argued that a legal field organized around the subject boundary of "climate adaptation" should be robust enough to recognize, explain, predict, and address equality or equity issues related to climate change and measures to address it. For example, Ruhl and Salzman argue that climate adaptation law should be guided by three "overarching normative goals": (1) reducing vulnerability [preventing harm from climate change]; (2) increasing resilience [recovering from climate change harm that is not avoided]; and (3) adaptation equity. ${ }^{105}$ The authors explain adaptation equity as follows:

[Adaptation equity] is designed to ensure that the benefits of promoting resilience and reducing vulnerability are distributed fairly. Whose vulnerability is reduced and whose is worsened? The same for resilience. Climate mitigation policy has triggered rousing debates over the equitable allocation of costs between nations and within nations. ${ }^{106}$

Ruhl and Salzman argue that Climate Adaptation Law would analyze law through the lens of their three normative goals, including adaptation equity. They argue that this crosscutting field would produce new insights into challenges to regulation caused by climate change that might otherwise be missed. Among those insights would be observations about the role and affects of organized resistance to injustices produced by climate related legal policies.

A field based on economic subordination and resistance offers a number of benefits. It acknowledges that climate change is related to power relations, both domestically and at the global level. Large and powerful business enterprises produce a substantial proportion of green house

Cole, Empowerment as the Key to Environmental Protection: The Need for Environmental Poverty Law (1992), 19 ECOLOGY L.Q. 641 (1992) [goal of environmental justice is to achieve structural societal change to achieve social justice]

${ }^{104}$ Kaswan, Fordham, supra note 99 at 169

${ }^{105}$ Ruhl \& Salzman, supra note 2 at 1020-1022.

${ }^{106} I d$. at 1022. 
gases, and citizens of wealthy nations contribute far more to climate harm than do citizens of poor countries. Resistance at both levels by citizens and activist organizations is resistance to power. Situating climate change and environmental degradation within a broader legal field organized around economic power and resistance would help legal scholars recognize patterns in the law that might otherwise be missed if we continue to compartmentalize labor law, environmental law, and environmental justice law. Moreover, it could provide a narrative around which we can make sense of the vast array of laws that affect and are affected by climate change.

But there are also limits to this approach, particularly at the domestic level. Resistance to economic subordination provides a means of bundling together disparate legal rules under a common banner. However, it does not provide us with an obvious normative agenda for law. Sometimes economic power causes harm to society, sometimes it does not; some resistance is valuable, some is disruptive and harmful. Economic power almost always benefits some segment of the population and harms others, while it has a neutral affect on other segments. Arthurs' proposed field might help us to recognize how law perpetuates economic power and regulates resistance to it, but it tells us little or anything about how to differentiate between good economic power and bad, and good resistance and bad.

This shortcoming matters greatly for the challenge of climate change. An economically powerful corporation may engage in activities that are very harmful to the environment. However, local communities who benefit from high paying jobs created by those corporations may not resist at all. In fact, they may be quite content, especially if the environmental harm is widely dispersed and not immediately apparent to the local community. Citizens outside the local community may not be aware of the harm being done, or may be unable or unmotivated to build a resistance movement. Some problems require collective government response, even when no 'resistance movement' emerges to address a problem. A legal field organized around economic power and resistance 
would have little if anything to tell us about when that response should occur, and what it should look like.

\section{B. Human Capital or Capacities Law}

Some labor law scholars have looked to Amartya Sen's 'human capabilities' theory as a promising new direction for their field. ${ }^{107}$ Environmental justice scholars too have identified Sen's capabilities approach as a promising avenue through which to realize the normative goal of justice in environmental regulation. ${ }^{108}$ Sen offers a normative foundation based in the idea of 'human freedom', understood as social and economic development measured by "the expansion of the 'capabilities' of people to live the kinds of lives that they value-and have reason to value." ${ }^{109}$ Langille has noted that labor law has always been about improving human freedom and, in particular, about "contributing to a more fulfilling and freer life" of the sort that people have reason to value. ${ }^{110} \mathrm{He}$ argued that by remapping labor law around Sen's concept of human capacities, the field could escape the constraints of the normative claim that "labor is not a commodity":

Our reason for being interested in contracts of employment is no longer simply an idea of justice or fairness which demands that we need to equalize bargaining power in a certain type of contract. Our new idea of human freedom provides an overarching framework for organizing much of what is not currently central to labor law, such as education, family care (including child care), training and active labor market policies, intellectual property, and so

\footnotetext{
${ }^{107}$ Langille, supra note 3; Brian Langille, Labour Law's Theory of Justice in Guy Davidov \& Brian Langille, (eds.), THE IDEA OF LABOUR LAw (2011) ["Idea of Labour Law"]; J. Brown, Simon Deakin, B. Wilkinson, Capabilities, Social Rights, and European Market Integration in R. Salais \& R. Villeneuve (eds), Europe AND THe Politics of CAPABilities (2004), 205. Note that the attempts to graft Sen onto a new map of labor law has also be criticized: See especially Finkin, supra note 51; Arthurs, supra note 51 at 24-26; Judy Fudge, Labor as a Fictive Commodity in THE IDEA OF LABOR LAW, 120 at 126-128.

${ }^{108}$ S. Roesler, Addressing Environmental Injustices: A Capability Approach to Rulemaking, $114 \mathrm{~W}$. VIRGINIA L. REV. 49 (2011)

${ }^{109}$ Amartya Sen, Development as Freedom (1999), 18; Amartya Sen, Capability and Well-Being in The Quality of Life 30 (Martha C. Nussbaum \& Amartya Sen, eds, 1993) [hereinafter Quality of Life]

${ }^{110}$ Langille, supra note 105 at 112.
} 
on, as well as much of what is currently central to labor law's familiar categories, such as employment standards..., collective bargaining, health and safety, human rights, etc. ${ }^{111}$

An important reminder emphasized in Sen's work is that, "human beings are not merely the means of production, but also the ends of the exercise." ${ }^{112}$ This simple yet powerful idea could guide a new legal field concerned with the regulation of "human capital deployment". We are still concerned with productivity and economic outcomes, but the normative goal that guides policy and lawmaking functions is maximization of human freedom. ${ }^{113}$

Professor Roesler advocates a capabilities approach to environmental justice, arguing that "to assess whether a particular environmental rule or policy is fair, we need an approach to justice that focuses on human lives, not just the environmental good or bad being distributed." ${ }^{114}$ That means assessing environmental rules according to "how they restrict or enhance opportunities people actually have to do and be the things they have reason to value." ${ }^{15}$ According to Roesler, Sen's capabilities approach "directs our attention to how forms of structural oppression, such as racism and class oppression, affect well-being, a concern at the heart of environmental justice." ${ }^{116}$ For Roesler, and other environmental justice scholars seeking to ground their discipline in a broader theory of justice, Sen's capabilities approach helps demonstrate how environmental injustice is associated with other injustices, including economic injustice. ${ }^{117}$

${ }^{111}$ Langille, supra note 107 at 33

${ }^{112}$ Sen, Development as Freedom, supra note 107 at 295.

${ }^{113}$ Langille, supra note 105 at 114.

${ }^{114}$ Roesler, supra note 106 at 71.

${ }^{115}$ Id.

${ }^{116}$ Id. at 77 .

${ }^{117}$ Id. at 78; Robert Kuchn, A Taxonomy of Environmental Justice, 30 ENVTL. L. RE. 10,681 (2000). See also Yang, supra note at 23:

In a sense, what [environmental justice] activists have been looking for are not just the minimum conditions necessary for human survival but also factors necessary for human thriving and quality of life. Concerns such as aesthetic and livable communities, places where pollution, odors, and traffic associated with such industrial facilities do not make it impossible to enjoy and play in one's backyard, connect with neighbors, and have a good sleep at night are indispensible in that respect. 
Sen is critical of the definition of sustainable development developed initially in the influential 1987 Brundtland Report, which was: "meeting the needs of the present without compromising the ability of future generations to meet their own needs". ${ }^{118}$ He notes that the definition had been refined by thinkers like Robert Solow to mean the preservation or improvement of the "standard of living" from one generation to the next. ${ }^{119}$ Sen notes that "sustaining living standards is not the same thing as sustaining people's freedom to have-or safeguard-what they value and to which they have reason to attach importance. ${ }^{120}$ Important human freedoms can be lost even though living standards are preserved.

Sen explains this point as follows:

In the ecological context, consider a deteriorating environment in which future generations are denied the opportunity to breathe fresh air (because of especially nasty emissions), but where those future generations are so very rich and so well served by other amenities that their overall standard of living may well be sustained. An approach to sustainable development on the Brundtland-Solow model may refuse to see any merit in protests against those emissions on the ground that the future generation will nevertheless have a standard of living at least as high as the present one. But that overlooks the need for antiemission policies that could help future generations to have the freedom to enjoy the fresh air that earlier generations enjoyed. ${ }^{121}$

Sen argues for a "freedom-based view of sustainability", preserving or expanding "substantive freedoms" without compromising the ability of future generations to have equal of more freedoms. ${ }^{122}$ Humans have good reason to value a clean environment and decent jobs, and therefore development policies should incorporate concern for the capacity of humans to enjoy both, now and in the future.

\footnotetext{
${ }^{118}$ See Amartya Sen, Why We Should Preserve the Spotted Owl. LONDON REview OF BoOKS (February 2004); Amartya Sen, The Ends and Means of Sustainability, 14 J. Human DEv. \& CAPABILITIES 6 [hereinafter Sustainability]

${ }^{119}$ Id. R. Solow, An Almost Practical Step Toward Sustainability, RESOURCES POLICY 162 (1993)

${ }^{120} I d$.

${ }^{121} I d$.

${ }^{122}$ Sen, Sustainability, supra note116 at 9-10.
} 
What precise policy prescriptions would result from a legal field organized around human capabilities and freedom is a matter of debate. However, a benefit of this approach is that it would seem to reject the simplistic contest between 'jobs and the environment'. Since humans have good reason to value both the capability to exercise human capital in productive means and to live in a world with a clean environment, legal policy would be encouraged to consider both and not trade one of against the other. It steers policy-makers away from too great a focus on short-term economic productivity and encourages a more thoughtful dialogue about how human freedom, today and in the future, are advanced by legal agendas.

\section{A Law of Just Transitions}

There is a third possibility for a new legal field organized around climate change, the environment, and work that draws on insights from the first two: Just Transitions Law (JTL) ${ }^{123}$ Since the 1990s, the labor movement has rallied around the concepts of 'green jobs' and a 'just transition' to a lower carbon economy in response to the challenges posed by climate change. ${ }^{124}$ At the core of a JT strategy is the insight that a transition towards a more sustainable, lower carbon economy change is necessary, and that this transition must be managed with an eye on protecting workers, families, and

${ }^{123}$ See A. Rosemberg, Building a Just Transition: The Linkages Between Climate Change and Employment, 2(2) INT. J. LAB. RES. 125-162 (2010); S. Stephenson, Jobs, Justice, Climate: Conflicting State Obligations in the International Human Rights and Climate Change Regimes, 42 OTTAWA L.J. 155-179 (2010); Peter Newell \& Dustin Mulvaney, The Political Economy of the Just Transition, 179(2) GEOGRAPHIC J. 132-140 (2013); Dimitris Stevis \& Romain Felli, Global Labour Unions and Just Transition to a Green Economy: International Environmental Agreements, in INTERNATIONAL ENVIRONMENTAL JUSTICE AND THE QUEST FOR A GREEN GLOBAL ECONOMY (Chukwumerije Okereke \& Timothy Ehresman, eds, forthcoming)

${ }^{124}$ Stevis, supra note 83; The Canadian Labour Congress has been active in developing the concept of 'just transitions'. See Canadian Labour Congress, Just Transition FOR WORKERS DURING ENVIRONMENTAL CHANGE (April 2000) http://www.canadianlabour.ca/newsroom/publications/just-transition-workers-during-environmental-change 
communities through the transitional stage and thereafter. ${ }^{125}$ Stevis summarizes the labor movement's turn to 'just transition' as follows:

Responding to climate negotiations and their significant implications for organizing the economy, national and global union agendas center around jobs that are environmentally benign ('green jobs') and a transition to a green economy that does not leave workers and communities behind ('just transition'). ${ }^{126}$

Unions argue that a JT will require worker and union solidarity and input at the domestic and supranational level, and a strong labor voice to dialogue with governments, business, environmentalists, and other important equity seeking organizations. ${ }^{127}$ At the core of a just transitions strategy is the belief that a transition to a 'greener' economy is a necessary and desirable response to threats caused by climate change, and that this transition should be guided by a theory of justice. JTL would draw on insights from the growing literature on sustainability transitions ${ }^{128}$ and environmental justice, but place greater emphasis on the role of law and legal policy in steering economies towards greener practices, with an eye on the distributive outcomes of this transition and the goal of promoting collective voice by workers, communities, and other stakeholders.

Given the prominent role of labor law in the just transitions vision, it is not surprising that the ILO has adopted 'just transitions' as a policy platform around which to organize its response to climate change:

It can be said that the notion of Just Transition is in line with the long-standing philosophy that has inspired the creation and the history of the International Labour Organization: the

\footnotetext{
${ }^{125}$ Id.; Rosemberg, supra note 121.

${ }^{126}$ Stevis, supra note 83 at 146.

${ }^{127}$ Id.; Virginia Silverman, Sustainable Alliances: The Origins of International Labor Environmentalism, 66 INT'L. LABOR \& WORKING-CLASS HIST. 118-35 (2004); Darryn Snell \& Peter Fairbrother, Toward a Theory of Union Environmental Politics: Unions and Climate Action in Australia LABOR STUDIEs J. (36(1) 83 (2011); Geoff Evans, A Just Transition From Coal to Renewable Energy in the Hunter Valley InT'L J. OF ENVIRONMENT, WorkPLACE, AND EMPLOYMENT 3(3-4) 175 (2007)

${ }^{128}$ See David Hess, Sustainability Transitions: A Political Coalition Perspective 43 ReseArCH Policy 278-283 (2014); Clark Miller, Alastair Iles, \& Christopher Jones, The Social Dimensions of Energy Transitions 22(2) SCIENCE AS CULTURE 135 (2013)
} 
idea that social concerns have to be part and parcel of economic decision-making, that the costs of economic transition should be socialized as much as possible, and that the economic management of the economy is best achieved when there is genuine social dialogue between social partners. ${ }^{129}$

There is obvious attraction in the concept of just transitions for legal scholars. It brings together environmental law, environmental justice, and labor law in interesting new ways that would allow the fields to work together on the shared legal response to climate change. It provides narrative and normative clarity around which a legal field can be developed. When we 'look out the window' at the legal world from the perspective of just transitions, we still see the same vast array of laws that we observed when we viewed law through the lens of climate change alone. But JTL could provide a means of organizing those laws into more coherent story and policy platform. JTL is interested in how law promotes, facilities, or impedes a transition towards a greener economy. This inquiry is guided by a theory of distributive justice.

\section{A. A Theory of Justice}

There is growing scholarly interest in 'just transitions' strategies, but virtually none of it is from labor

law scholars. However, a legal field of JTL would include much that is familiar to labor lawyers. A 'just' transition adopts the idea that 'labor is not a commodity' and all that idea has meant to labor law over the years. It reminds us that climate change policy and transitional strategies must not abandon the goal of decent jobs, opportunities for workers, and economic development, if it is to attract broad public and political support. A just transition envisions an active state using law to tame market forces, which if left unchecked, could produce environmental and economic catastrophe. Professor Stevis describes this perspective as 'environmental Keynesianism. ${ }^{\text {,30 }}$

\footnotetext{
${ }^{129}$ Dan Cunniah, Preface, 2(2) INT. J. LAB. RESEARCH 121-124 (2010), 123.

${ }^{130}$ Stevis, supra note 83 at 154.
} 
JTL is guided by a theory of justice encapsulated by the following normative claims (NC). Firstly, climate change is a pressing global problem that market forces alone will not adequately address. Therefore, states should respond through public policy and law (NC1). Secondly, public policy should encourage a transition towards 'greener', lower carbon economies (NC2). Thirdly, there will be social and economic costs and benefits associated with climate change, and with the transitional policies aimed at responding to it, and those costs and benefits will also not be equitably distributed by market forces alone. Therefore, governments should seek to minimize the economic and social harms associated with the desired transition to a greener economy, and attempt, through law and policy, to distribute those harms and any resulting benefits in an equitable manner (NC3).

Each of the above claims is challengeable, and of course there is considerable room for debate about which laws and policies would best achieve the objective of a just transition to a lower carbon economy, or whether a just transition is possible or even a desirable objective. ${ }^{131} \mathrm{JTL}$ scholars would find early work defending the normative claims upon which the field's foundation rests, or arguing over what those claims should be. But this is true of all new legal fields, and many well-established ones-such as labor and environmental law. These are healthy debates that help shape the legal field and solidify its theoretical core.

$\mathrm{NC} 1$ and NC2 are widely accepted by the scientific, political, environmental (even religious ${ }^{132}$ ) communities. ${ }^{133}$ Broad consensus around them explains why the United Nations has for over twenty

\footnotetext{
${ }^{131}$ There is already a literature critical of the "just transition" agenda: Helen Masterman-Smith, Green Collaring a Capital Crisis? 20(3) LABOUR \& INDUSTRY 317 (2010). See also Richard Epstein, SIMPLE RULES FOR A COMPLEX WORLD (1995), at 286-299 for discussion of competing approaches to regulating environmental threats, including pollution, strip mining, damage to wetlands and habitant, and dirty coal.

${ }^{132}$ See the extraordinary Encyclical Letter of Pope Francis, On Care for Our Common Home, http://i2.cdn.turner.com/cnn/2015/images/06/18/papa-francesco_20150524_enciclica-laudatosi_en.pdf
} 
years convened international conferences and promulgated global framework agreements and protocols aimed at finding political solutions to global warming. ${ }^{134} \mathrm{NC} 3$ is a key theme in environmental justice scholarship, and aligns closely with Ruhl and Salzman's concept of 'adaptation equity'. ${ }^{135}$ Environmental justice and law scholars have not focused much on labor market policies, but JTL would invite labor law scholars into the climate change discussion, adding their expertise in matters of equitable distribution of work-related costs and benefits and how law can organize and promote collective voice in key public policy and economic debates.

Just as labor law's traditional theory of justice, discussed in Part 4 above, guided early labor law scholars as they developed their discipline, so too could NC3 help JTL scholars chart the early maps of their new legal discipline. NC3 informs us about what legal material we are interested in when we look out the window at the cluttered world of laws relating to climate change through the lens of JTL. It is those laws and policies that are directed at, or that affect, the transition towards greener economies, and that influence how the benefits, harms, and risks associated with that transition are distributed throughout societies. The lens through which we would view this subject matter is JTL's theory of justice, which is guided by NC3. This approach to defining the contours of the legal field of JTL is similar to the framing of labor law, which is distinguished from other legal fields by its subject matter (work and employment) and its traditional theory of justice, as expressed in the slogans "labor is not a commodity" and "inequality of bargaining power", as discussed earlier.

\section{B. Transitional LaW}

Finally, JTL is transitional law. "Transitions" refers to a process of system wide change designed to move from one state of being to another, in this case, from a high carbon economy towards a lower

\footnotetext{
${ }^{133}$ Eric Posner \& Cass Sunstein, Climate Change Justice, PUBLIC LAW AND LEGAL THEORY WORKING PAPER NO. 177 (2007)

${ }_{134}$ United Nations Framework Convention on Climate Change Background: http://unfccc.int/essential_background/items/6031.php

${ }^{135}$ Ruhl \& Salzberg, supra note 3; Roesler, supra note 106.
} 
carbon economy. According to Rotmans, Kemp, and van Asselt, this transition process requires a clear vision, and "an important task for government is to assist in formulating that vision, and to inspire and mobilize other actors." ${ }^{\text {136 }}$ As noted by the Canadian Labour Congress in an early paper promoting a just transitions strategy, governments need to "anticipate economic change and plan transition...as an integral part of industrial change". ${ }^{137}$ This means working just transitions objectives into policy planning at all stages. Law has an important role to play in that process, including labor law.

Labor law was itself a transitional legal field; it emerged in tandem with industrialization and the growth in waged labor and accompanying worker exploitation and industrial conflict, and the rise of the welfare state as a means of responding to perceived market failures. ${ }^{138}$ Labor Law was the means used by the state to plan a capitalist economy that incorporated justice issues into labor market outcomes. ${ }^{139}$ Social insurance schemes, such as unemployment insurance and workers' compensation were part of this movement. ${ }^{140}$ However, there are other well-known examples of transitional legal strategies. One is the Treaty establishing the European Coal and Steel Community (or ESTC Treaty) of $1951 .^{141}$ The ESTC Treating was ostensibly a regional trade agreement, but its grander objective was a planned transition of the post World War II European market in coal and steel that included a social dimension. ${ }^{142}$ Political leaders recognized that many enterprises would collapse under a system of European economic integration and legal ordering was intended to

${ }^{136}$ Jan Rotmans, Rene Kemp, Marjorlein van Asselt, More Evolution than Revolution: Transition Management in Public Policy 3(1) Foresight 15 at 25 (2001)

${ }^{137}$ Canadian Labour Congress, supra note 124.

${ }^{138}$ Mark Barenberg, The Political Economy of the Wagner Act: Power, Symbol, and Workplace Cooperation, 106 HARVARD LAW REVIEW 1381 (1993)

${ }^{139} I d$.

${ }^{140}$ Simon Deakin, The Contribution of Labour Law to Economic and Human Development, in THE IDEA OF LABOUR LAW, supra note 105, 156 at 164-165.

${ }^{141}$ Treaty Constituting the European Coal and Steel Community, http://www.consilium.europa.eu/uedocs/cmsUpload/Treaty\%20constituting\%20the \%20E uropean\%20Coal\%20and\%20Steel\%20Community.pdf ${ }^{142}$ G. Bebr, The European Coal and Steel Community: A Political and Legal Innovation, 65 YALE LAW JOURNAL 1 
provide protections to the victims during the transition stage, as explained by Professor Gerhard Bebr:

... the Treaty provides for a five- to seven year period of adjustment, during which the Community, in cooperation with the Member States, will financially assist and grant temporary protection to the weaker coal and steel enterprises. Financial assistance will aid beleaguered enterprises in specializing their production, modernizing their methods, or otherwise modifying their activities, even to the extent of creating new ones outside the coal and steel industries. The enterprises which are forced to close are given preference in establishing new industries. Before granting such financial assistance, the Community must find the proposed project economically sound and capable of providing employment for the released miners and steel workers. If these adjustments cause unemployment, the Community contributes to the employee's unemployment compensation. The released workers will also receive financial assistance for their re-training and transfer to new industries. ${ }^{143}$

There is already a rich political science literature on "sustainability transitions". ${ }^{14}$ This literature emphasizes the role of public policy and the need to harness private actors towards the objective of transitioning to a lower carbon economy. However, the role of labor law in the planning and implementation of transitional strategies, and the short and long term affects on labor market outcomes of those strategies, have been underexplored. ${ }^{145}$ JTL would provide the framework through which labor law insights could be incorporated into the sustainability transitions discourse, adding important depth to our understanding of the transition process.

The focus of inquiry is on legal strategies to transition to a lower carbon economy, and how those strategies will produce "just", or equitable outcomes. JTL is guided by a series of inquiries: What laws and policies could encourage a transition away from high carbon industries to lower carbon

${ }^{143}$ Id. at 11

${ }^{14}$ See, e.g., Hess, supra note 126; Adrian Smith, Andy Stirling, \& Frans Berkhout, The Governance of Sustainable Socio-Technical Transitions, 34 RESEARCH POLICY 1491-1510 (2005); Jochen Markard, Rob Raven, \& Bernhard Truffer, Sustainability Transitions: An Emerging Field of Research and Its Prospects, 41 ResearCh POLICY 955-967 (2012); Elizabeth Shove \& Gordon Walker, Caution: Transitions Ahead: Politics, Practice, and Sustainable Transitions Management Environment and Planning 39(4) ENVIRONMENT ANd PlanNing 763 - 770 (2007)

${ }^{145}$ But see Dimitris Stevis, US Labour Unions and Climate Change: Technological Innovations and Institutional Influences in Neil Harrison \& John Mikler (eds), Climate InNOvations: Liberal Capitalism and Climate Change (2014), 164 
industries? Who will participate in the decisions about how a transition should be implemented, and how should law manage that participation? Who will most benefit by these transitional policies, and who is most at risk from them? And what laws and policies can achieve a more equitable distribution of harms, risks, and benefits associated with the transition? Since transitional policies will inevitably involve job displacement, collective negotiations, a requirement for new labor force skills and retraining, transitional funding schemes to support workers as they transition to the new economy, and decent jobs once those new 'green' industries develop, labor lawyers should have a lot to contribute to JTL.

\section{Concluding Thoughts on Just Transitions Law: A Way Forward}

A challenge for the development of JTL is that the subject draws from so many diverse legal fields. The same challenge confronts Arthurs' "law of economic subordination and resistance", and most efforts to remap legal boundaries. Labor lawyers know a lot about labor laws and policy that pursue decent jobs, but next to nothing about cap and trade rules or environmental assessment laws. Environmental lawyers may know something about property and ambient air emissions controls and reporting laws, but few can explain whether unemployment insurance laws fund retraining for workers who lose their jobs as a result of their coal-mining employer being phased out. Environmental justice scholars can explain how land use planning laws produce inequitable environmental outcomes, but not whether occupational health and safety laws do a good job of ensuring windmill factories are safe. ${ }^{146}$

${ }_{146}$ See European Agency for Safety and Health at Work, Working IN THE Wind EnERgY SECTOR (2014), https://osha.europa.eu/en/highlights/safe-working-in-the-wind-energy-sector; U.S. Department of Labor, Green Job Hazards: Wind Energy [https:/www.osha.gov/dep/greenjobs/windenergy.html] 
A legal field organized around the idea of just transitions would require lawyers, legal scholars, and policy-makers to expand their areas of expertise, and for experts from different legal fields to converge around a new narrative. This presents a challenge, but also a great opportunity at a crucial moment in time when governments are searching for mechanisms and strategies to plan for climate change and the transition towards a greener economy that accounts for the economic and social consequences. JTL would take a holistic view of the role of law and legal planning by drawing together experiences and knowledge from all those legal fields that have relevance to the transitioning process.

A full canvassing of the legal issues and subject matter that would be encompassed in a law of just transitions must be left for another project. However, we can trace out in broad-brush strokes what the first Just Transitions Law textbook might include. The book would no doubt include some statistical evidence about climate change and its current and potential impact on the environment and labor markets, not dissimilar from how labor law texts include labor market statistics to provide the background setting to the legal discussion. ${ }^{147}$ In traditional textbook fashion, it would open with a review of the theory, or 'constituting narrative', around which the legal field is organized. It would explain that JTL encompasses laws, policies, and norms that promote, steer, or impede the transition towards a lower carbon economy, and that JTL views those laws through the lens of its normative agenda, as described in NC1 thru NC3.

The text then would be divided into legal subject matter. There is considerable room for debate over what materials should be included, and how they should be organized. In Appendix A, I have sketched a rough draft of subject matter that would probably appear in some form, although this is no doubt an incomplete list. The traditional subject matter of labor law would play a prominent

\footnotetext{
${ }^{147}$ See, e.g., Marion Crain, Pauline Kim, Michael Selmi, WORK LAW: CaSES AND Materials, $2^{\text {nd }}$ (2010), chapter 2
} 
role in the JTL text. The protection and creation of good jobs remains an objective of JTL, and labor law is the legal means by which the state promotes good jobs. JTL promotes collective voice and participation by civil society in the setting of transitional goals, and freedom of association and the laws we use to instantiate it are crucial in that regard. In JTL, collective bargaining, while still important, is just one form of collective voice among others. For example, the right to participate and to be consulted about workplace closures, relocations, and economic transitions might extend beyond unions to other groups, such as environmental justice organizations, concerned citizens and community groups, business, and others. JTL would be interested in the legal mechanisms used to ensure and manage the participation of civil society in important decisions relating to the transition process.

Some traditional areas of labor law will take on renewed importance in JTL, or the emphasis within those areas will change. For example, unemployment insurance rules are especially significant in the context of transitioning from one type of economy to another, as many workers will become redundant. ${ }^{148}$ Unemployment insurance laws must recognize that jobs are being lost as part of a deliberate government strategy to phase out certain dirty industries, and that the costs of this strategy should be shared across society and not placed primarily on the shoulders of workers. JTL scholars will be interested in how unemployment laws, as well as laws governing access to retraining initiatives, contribute to an equitable distribution of benefits and harms associated with the transition. Pension laws may need to be reviewed and possibly revised, for example to ensure that workers receiving retraining for skills in the new lower carbon economy are not punished in terms of lower contributory earnings, or to permit workers nearing retirement age to bridge their

\footnotetext{
${ }^{148}$ See e.g., Canadian Labour Congress, supra note 124: "A necessary foundation for an effective Just Transition program is effective unemployment insurance. An effective unemployment insurance program is one which provides an adequate degree of income replacement, has reasonable qualifying requirements, provides for a benefit period sufficient to support most adjustment needs and is sufficiently flexible to permit recipients to engage in activities relevant to employment adjustment while receiving benefits."
} 
pensions. A JTL strategy takes a holistic view of labour market participation, and therefore it is not surprising that the European concept of 'flexicurity' appears in just transitions discourse. ${ }^{149}$

However, our JTL textbook will include much more than just the subject matter of traditional labor law. Environmental law will obviously be an important part of the book. The growing numbers of laws that target climate change, often today lumped under the legal category of 'climate change law' are of interest to JTL. These include, for example, emissions controls laws, and market-based legal models to discourage green house gases, such as 'cap and trade' laws. ${ }^{150}$ These laws form an important part of the legal response to climate change and the strategy to encourage a transition to a greener economy. However, JTL studies these laws through the lens of its theory of justice, emphasizing the extent to which these laws produce or will produce a 'just transition'.

Other legal fields are also of interest to JTL, including corporate and securities laws. For example, securities laws that require public reporting on environmental and social and labor practices could be relevant in JTL. ${ }^{151}$ The laws that govern shareholder rights, and in particular the right to initiate shareholder resolutions or proxies addressing environmental and labor practices may be of interest to JTL. ${ }^{152}$ Even the rules of corporate chartering, and the potential for governments to condition charters on the advancement of the public good have potential relevance. ${ }^{153}$ Immigration and mobility laws will be important, since they will affect the ability of workers displaced by climate

\footnotetext{
${ }^{149}$ UNEP, supra note 1, 291. Flexicurity describes a package of legal reforms that seeks to give employers greater labour force flexibility, while also providing workers with access to policy tools to transition to new jobs over the course of their working lives.

${ }^{150}$ Dernbach \& Kakade, supra note 14; Peel, supra note 62.

${ }^{151}$ Cynthia Williams, The Securities and Exchange Commission and Corporate Social Responsibility, 112 HARVARD LAW REV. 1197 (1999)

${ }^{152}$ Geoffrey Rapp, A New Direction for Shareholder Environmental Activism: The Aftermath Caremark 31(1) William \& Mary Environmental Law \& Policy Rev. 163 (2006)

${ }^{153}$ Charles Cray, Revising Corporate Charters Summit on the Future of the Corporation, Paper No. 7, (2007) http://www.corporatepolicy.org/pdf/charters.pdf
} 
change or economic transitioning to move to the location of new jobs. ${ }^{154}$ Land use laws, a traditional focus of the environmental justice movement, will influence the impacts of risks from transition, including decisions about where potentially harmful carbon or pollutants are stored and where new 'clean' industries are located, decisions that can have substantial implications for the equitable distribution of risks and benefits associated with the transition. Tax and budget laws create incentives and disincentives during the transition process, as do government decisions on infrastructure and stimulus spending that can either lock the economy into old patterns of high carbon economics or chart a transitional path to a lower carbon economy.

Of course, as with any attempt to persuade readers of the value of new legal categories, advocates of a legal field organized around 'just transitions' will need to demonstrate that the exercise is worthwhile. I have argued that JTL would bring together disparate legal fields in an original and potentially useful way by encouraging a cross-disciplinary approach to the complex public policy challenge of how to transition away from high carbon economies while not at the same time sacrificing the economy, employers, workers, communities, and families. That may be too much to ask of a legal field, especially one in its infancy. Yet if governments are to confront climate change, and to use law as a means to facilitate a transition away from high carbon economies, a just transition' should be the guiding theme. Therefore, regardless of whether JTL rises to the level of a distinct legal field, it is deserving of a prominent place at tables wherever climate change and law are being discussed.

\footnotetext{
${ }^{15 t}$ Sujatha Byravan \& Sudhir Rajan, Providing New Homes for Climate Change Exiles 6(2) Climate Policy; Stephanie Dickson, Sophie Webber, \& Tim Takaro, PreParing B.C. For Climate MigRATION (2014) Canadian Centre for Policy Alternatives https://www.policyalternatives.ca/sites/default/files/uploads/publications/BC\%20Office/2014/11/ccp a-bc_ClimateMigration_web.pdf
} 
Appendix A: A Taxonomy of Just Transitions Law

\begin{tabular}{|c|c|}
\hline Existing Legal Field & Potential Relevance for JTL \\
\hline $\begin{array}{l}\text { Labor Law } \\
\text { - } \text { Employment Standards } \\
\text { - } \quad \text { Collective Bargaining Laws } \\
\text { - } \quad \text { Unemployment Insurance } \\
\text { - } \quad \text { Training and Apprenticeships } \\
\text { - Occupational health and safety } \\
\text { - Workers' compensation }\end{array}$ & $\begin{array}{l}\text { Regulates notice and consultation requirements } \\
\text { in cases of workplace closures or transitions, } \\
\text { and 'transfers of undertakings'. } \\
\text { Promotes collective voice by unions and other } \\
\text { worker associations, and employers and } \\
\text { employer associations. } \\
\text { Unemployment insurance laws provide } \\
\text { economic cushion for temporary joblessness, } \\
\text { including through transitional phases. } \\
\text { access by workers to opportunities and funding } \\
\text { for skills retooling and upgrades. }\end{array}$ \\
\hline
\end{tabular}




\begin{tabular}{|c|c|}
\hline & $\begin{array}{l}\text { Pension laws provide income security to older } \\
\text { workers who may lose jobs due to transitions. } \\
\text { OHS laws target unsafe workplaces, including } \\
\text { "old" high carbon workplaces and "new" } \\
\text { greener workplaces. }\end{array}$ \\
\hline Environmental Law & $\begin{array}{l}\text { Laws targeting climate change are an important } \\
\text { means by which governments pursue a } \\
\text { transition away from high carbon economies. } \\
\text { How do these laws promote a transition? Do } \\
\text { they promote a 'just' transition? }\end{array}$ \\
\hline Tax, Subsidies, and Budget Laws & $\begin{array}{l}\text { Government infrastructure programs and } \\
\text { funding that promote 'green jobs', or sustain } \\
\text { high carbon producing industries. } \\
\text { Tax laws incentivize or discourage behavior } \\
\text { relevant to a transition to a lower carbon } \\
\text { economy. }\end{array}$ \\
\hline
\end{tabular}




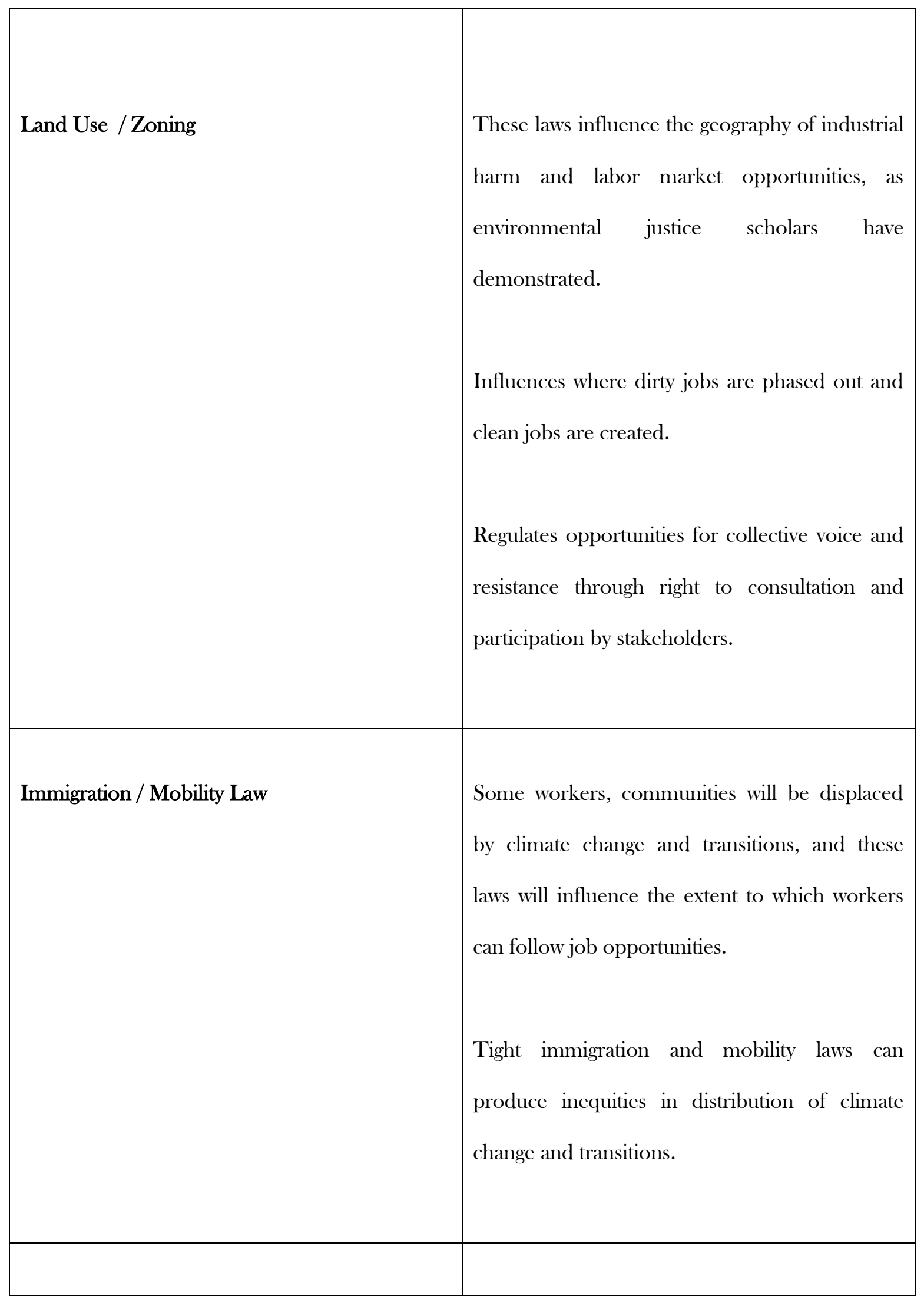




\begin{tabular}{|l|l|}
\hline Corporate and Securities Laws & $\begin{array}{l}\text { Laws regulating transparency requirements } \\
\text { including reporting on emissions and materially } \\
\text { relevant legal risks. }\end{array}$ \\
Laws controlling activist shareholder proposals \\
related to social (including labor and \\
environment-related matters). \\
Corporate law's chartering system can be used \\
to limit incorporation to businesses that operate \\
in the public interest.
\end{tabular}

